\title{
KEMAMPUAN BELAJAR MANDIRI MAHASISWA UNIVERSITAS NEGERI JAKARTA
}

\author{
Suprayekti
}

\begin{abstract}
This research was intended to find out what and how the independent learning competency of the students of State University of Jakarta. Data were collected by using questionnaires. The scope of study was limited to the students of School of Education, State University of Jakarta. Samples were chosen by using purposive sampling technique.

Research findings show that: (1) based on independent learning method, all students of State University of Jakarta can implement independent learning, (2) based on the goals of independent learning the students are expected to have responsibility to themselves and the implementation of independent learning. Further, this research gives some suggestions such as: (1) university, especially School of Education should provide infrastructure, trainings, and compatible components; (2) the lectures should have appropriate knowledge and concept in independent learning; and (3) the students should practice constructivism and active learning as well as to learn without depending on other people.
\end{abstract}

Keywords: independent learning, constructivism, active learning.

\section{PENDAHULUAN}

\section{Latar Belakang Masalah}

Dalam era informasi dewasa ini, telah terjadi percepatan perubahan dalam berbagai hal yang menuntut setiap individu untuk terus beradaptasi dengan perubahan yang terkadang tidak disadari. Untuk dapat menyesuaikan atau beradaptasi dengan perubahan yang terjadi maka setiap individu dituntut untuk terus belajar sepanjang hayat. Belajar merupakan fenomena alamiah yang bersifat kontinu.

Mayor (1998) mengatakan bahwa dalam era ekonomi dewasa ini, ketika teknologi informasi sangat dominan maka pendidikan adalah raja, tidak hanya untuk persekolahan/universitas tapi juga pendidikan sepanjang hayat. Dari pendapat di atas dapat dikatakan bahwa proses belajar tidak hanya terjadi jika dikondisikan saja tetapi dapat terjadi di mana saja dan kapan saja, serta tidak mengenal batas waktu maupun usia. Berkaitan dengan hal ini, penelitianpenelitian tentang pendidikan orang dewasa telah menunjukkan betapa pentingnya untuk memiliki keterampilan belajar mandiri. Down (1994) dan Mullen (1997), dari hasil penelitiannya menunjukkan bahwa setiap organisasi bisnis mengharapkan para lulusan perguruan tinggi memiliki kemampuan dalam memecahkan masalah (problem solving), beradaptasi dengan orang lain (http://www.tp.edu.sg/ pblconference/full/ireneSiaw.pdf). Isu ini, telah sedemikian pentingnya dan telah menjadi visi dari beberapa universitas di dunia, seperti Penn' State University (http//www.utreach.edu/DE/il.html),
Cuya Hoga Community College (http:// www.dlc.trec.cc.ch.us/doc/il.html), serta Open University of Hongkong (http://www.tp.edu.sg).

Belajar mandiri dapat dipandang sebagai suatu metode atau tujuan. Sebagai metode, belajar mandiri menunjukkan adanya upaya pembelajaran dengan cara atau sistem belajar mandiri, sedangkan sebagai tujuan mengandung makna bahwa suatu aktivitas tertentu ditujukan untuk membentuk kemampuan belajar mandiri. Kebutuhan akan kemampuan belajar mandiri pada jenjang universitas ditujukan untuk memecahkan masalah (problem solving) dengan baik, dari masalah-masalah yang bersifat sosial ataupun sampai pada tingkatan ilmiah yang memerlukan datadata empiris melalui percobaan dan pengamatan.

Aktivitas kehidupan kampus di Universitas Negeri Jakarta (UNJ), sebagaimana pula di perguruanperguruan tinggi lainnya, baik secara langsung ataupun tidak langsung telah memberikan kontribusi terhadap pembentukkan kemampuan belajar mandiri melalui pengalaman belajar di universitas, partisipasi aktif dalam kegiatan berorganisasi, dan metode pembelajaran yang dilakukan dosen juga memberikan kontribusi dalam pembentukkan sikap dan kemampuan belajar mandiri.

Dari fenomena di atas maka kemampuan belajar mandiri pada jenjang universitas harus dikembangkan untuk meningkatkan kualitas kelulusan mahasiswa UNJ dalam memecahkan masalah dan menghadapi perubahan dunia.

\section{Identifikasi Masalah}

Berdasarkan latar belakang yang telah diuraikan, dapat diidentifikasi beberapa masalah 
sebagai berikut. (1) Bagaimanakah kemampuan belajar mandiri mahasiswa UNJ? (2) Apakah terdapat perbedaan kemampuan belajar mandiri antara mahasiswa yang ber-IPK tinggi dan ber-IPK rendah? (3) Apakah terdapat perbedaan kemampuan belajar mandiri antara mahasiswa lama dengan mahasiswa baru? (4) Apakah terdapat perbedaan kemampuan belajar mandiri antara mahasiswa aktif kampus dengan mahasiswa nonaktif kampus?

\section{Pembatasan Masalah}

Mengingat banyaknya masalah yang teridentifikasi dan terbatasnya waktu, kemampuan, dan biaya yang peneliti miliki, penelitian ini dibatasi pada: (1) masalah: kemampuan belajar mandiri mahasiswa UNJ dilihat sebagai suatu aspek metode dan aspek tujuan; (2) responden penelitian: populasi terjangkau penelitian adalah mahasiswa Fakultas Ilmu Pendidikan (FIP) UNJ; (3) tempat penelitian: dibatasi pada FIP UNJ; dan (4) kurun waktu penelitian: penelitian ini berlangsung selama mulai bulan Maret 2007.

\section{Perumusan Masalah}

Dari identifikasi masalah di atas maka dapat dirumuskan masalah penelitian ini adalah: "Bagaimanakah kemampuan belajar mandiri mahasiswa UNJ sebagai suatu aspek metode dan tujuannya?"

\section{Tujuan Penelitian}

Tujuan utama penelitian ini adalah untuk mengetahui kemampuan belajar mandiri mahasiswa UNJ.

\section{Kegunaan Penelitian}

Hasil penelitian ini dapat digunakan untuk menentukan kebijakan mengenai (1) penting tidaknya mengintegrasikan metode pembelajaran yang dapat mengembangkan kemampuan belajar secara mandiri bagi mahasiswa, (2) penting tidaknya perancangan lingkungan belajar yang dapat mengembangkan kemampuan belajar mandiri mahasiswa, (3) penting tidaknya upaya menghidupkan organisasi-organisasi kemahasiswaan sebagai wadah pengembangan kemampuan belajar mandiri, dan (4) penting tidaknya merancang dan mengembangkan pelatihan keterampilan belajar mandiri bagi para mahasiswa UNJ.

\section{KAJIAN TEORETIS}

\section{Hakikat Belajar}

Pada dasarnya belajar mengandung arti yang luas. Heinich et.al. (1993:4) berpendapat bahwa belajar merupakan perkembangan tingkah laku, kecakapan, ataupun pengetahuan baru ketika individu berinteraksi dengan informasi dan lingkungan. Mengacu pada pandangan constructivism, belajar adalah peristiwa di mana pemelajar secara terus menerus membangun gagasan baru atau memodifikasi gagasan lama dalam struktur kognitif yang senantiasa disempurnakan. Pandangan ini sejalan dengan pandangan Raka Joni (1993), ahli pendidikan Indonesia, yang mengungkapkan titik pusat hakikat belajar sebagai pengetahuanpemahaman yang terwujud dalam bentuk pemberian makna secara konstruktivistik oleh pemelajar kepada pengalamannya melalui berbagai bentuk pengkajian yang memerlukan pengerahan berbagai keterampilan kognitif di dalam mengolah informasi yang diperoleh melalui alat indera (http://www.depdiknas.go.id/ jurnal $/ 35 /$ mengubah_wawasan_peran.htm).

Dari uraian di atas terlihat bahwa inti belajar yaitu proses pengalaman interaksi dengan informasi dan lingkungan yang menyebabkan terjadinya perubahan atau perkembangan pengetahuan, tingkah laku, sikap, ataupun kecakapan dalam diri individu secara terus menerus membangun gagasan baru atau memodifikasi gagasan lama dalam struktur kognitif yang senantiasa disempurnakan. Belajar dipengaruhi oleh pengalaman, interaksi lingkungan perasaan emosional, nilai-nilai, dan persepsi yang dibentuk oleh individu.

\section{Hakikat Belajar Mandiri}

Ada beberapa istilah yang mengacu pada pengertian yang sama tentang belajar mandiri. Istilahistilah tersebut adalah (1) independent learning, (2) selfdirected learning, dan (3) autonomous learning (http:// www.brookes.ac.uk/services/ocds/2-laerntch/ indepedent.html). Rowntree (1992:61), dengan mengutip penjelasan Lewis dan Spencer (1986) menjelaskan pengertian belajar mandiri dalam konteks pendidikan terbuka. Ia mengatakan bahwa ciri utama dari pendidikan terbuka adalah adanya komitmen untuk membantu pemelajar memperoleh independensi dan kemandirian. Dalam keadaan yang demikian, pemelajar mempunyai kemandirian dalam mengambil atau menentukan keputusan sendiri tentang: (1) tujuan atau hasil belajar yang ingin dicapai; (2) mata ajar, tema, topik, atau isu yang akan dipelajari; (3) sumbersumber belajar dan metode yang akan digunakan; dan (4) kapan, bagaimana serta dalam hal apa keberhasilan belajarnya akan diuji (dinilai).

Keesten (1987) menjelaskan belajar mandiri sebagai suatu pembelajaran di mana pemelajar, dalam kaitannya dengan orang-orang lain yang relevan, dapat mengambil keputusan yang 
diperlukan untuk mencapai kebutuhan belajarnya sendiri (http://www.sasked.gov.sk.ca/does/policy/ cels/cl17.html). Pernyataan ini menjelaskan beberapa unsur dari konsep belajar mandiri. Pertama, kebutuhan belajar adalah tanggung jawab pemelajar itu sendiri. Kedua, pemelajar memegang kendali dalam pengambilan keputusan untuk mencapai kebutuhan belajar tesebut. Terakhir, dalam upaya mencapai kebutuhan belajarnya tersebut, mereka secara individu atau kelompok dapat meminta bantuan kepada orang-orang yang relevan, seperti guru/tutor/dosen, dan teman.

Dari definisi dan pendapat-pendapat para ahli tentang belajar mandiri maka dapat ditarik kesimpulan bahwa belajar mandiri adalah suatu proses belajar yang dilakukan oleh si pemelajar dengan mengkonstruk pengetahuan, informasi dari lingkungannya dengan kebebasan dan tanggung jawab dalam merencanakan dan melakukan kegiatan-kegiatan yang mendorong ke arah terjadinya belajar. Proses belajar tersebut dapat berjalan dengan memperhatikan aspek sebagai berikut.

1. Membangun motivasi belajar mandiri

Ada beberapa faktor yang menyebabkan keberhasilan atas sesuatu, termasuk dalam belajar. Menurut Reey (1994:39) salah satu faktor penyebab kegagalan belajar adalah lemahnya motivasi, di samping pengalaman masa lalu, lingkungan yang tidak sesuai dan lain-lain.

Keller, seperti dikutip oleh Frith (1997:6) mengembangkan suatu model desain motivasi yang dikenal dengan model ARCS (Attention-Relevance-Corifidence-Satisfaction). Model desain motivasi ini memandang motivasi sebagai urutan peristiwa yang terdiri dari perhatian, relevansi, kepercayaan, dan kepuasan. Berikut ini adalah tabel strategi yang dapat dilakukan oleh guru/tutor untuk rnembangun motivasi dengan model ARCS dari Keller.

Tabel 1. Strategi Pembelajaran untuk Meningkatkan Motivasi Berdasarkan Model ARCS

\begin{tabular}{|c|c|}
\hline \multirow{3}{*}{$\begin{array}{l}\text { Mengupayakan dan } \\
\text { mempertahankan } \\
\text { perhatian }\end{array}$} & $\begin{array}{l}\text { Dapatkan perhatian pemelajar dengan menggunakan pendekatan yang } \\
\text { tidak diduga oleh mereka (kejutan). }\end{array}$ \\
\hline & $\begin{array}{l}\text { Rangsang rasa ingin tahu dengan menyajikan permasalahan yang } \\
\text { mengandung misteri (teka-teki) atau mengundang rasa ingin tahu. }\end{array}$ \\
\hline & $\begin{array}{l}\text { Pertahankan perhatian pemelajar dengan memvariasikan penyajian } \\
\text { pembelajaran. }\end{array}$ \\
\hline \multirow{3}{*}{$\begin{array}{l}\text { Menguatkan } \\
\text { relevansi }\end{array}$} & $\begin{array}{l}\text { Kuatkan persepsi dengan menyatakan atau menjelaskan hubungan apa } \\
\text { yang dipelajari dengan tujuan pribadi pebeIajar. }\end{array}$ \\
\hline & $\begin{array}{l}\text { Berikan peluang/kesempatan kepada pemelajar untuk mencocokkan } \\
\text { apa yang dipelajarinya dengan pengalaman sebelumnya. }\end{array}$ \\
\hline & $\begin{array}{l}\text { Tingkatkan kefamiliaran dengan menghubungkan pengalaman } \\
\text { pemelajar sebelumnya. }\end{array}$ \\
\hline \multirow{2}{*}{$\begin{array}{l}\text { Membangun } \\
\text { kepercayaan }\end{array}$} & $\begin{array}{l}\text { Ciptakan harapan positif untuk sukses dengan membuat atau } \\
\text { menyampaikan tujuan pembelajaran yang jelas dan berguna bagi } \\
\text { mereka. }\end{array}$ \\
\hline & $\begin{array}{l}\text { Berikan pemelajar tanggung jawab untuk mengendalikan (mengontrol) } \\
\text { belajarnya sendiri. }\end{array}$ \\
\hline \multirow{3}{*}{$\begin{array}{l}\text { Menghasilkan rasa } \\
\text { puas }\end{array}$} & $\begin{array}{l}\text { Ciptakan konsekuensi alami dengan memberikan peluang/kesempatan } \\
\text { kepada pemelajar untuk menggunakan/mempraktekkan keterampilan } \\
\text { yang baru diperolehnya. }\end{array}$ \\
\hline & $\begin{array}{l}\text { Jika tidak diberikan konsekuensi alami, gunakan hadiah simbolik yang } \\
\text { positif (positive symbolic reward) }\end{array}$ \\
\hline & $\begin{array}{l}\text { Menjamin kemerataan dengan mempertahankan standar } \\
\text { konsisten dan mencocokkan hasil dengan harapan. }\end{array}$ \\
\hline
\end{tabular}

\section{Faktor penunjang dalam belajar mandiri}

Berikut ini adalah beberapa rekomendasi yang diajukan oleh beberapa penulis seperti Ash, 1985; Bauer, 1985; Brocket dan Hiemstra, 1985; Brookfield, 1985; Cross, 1978; Hiemstra, 1982, 1985; dan Reisser, 1973 tentang cara terbaik tutor/instruktur dalam memfasilitasi pembelajaran mandiri: (a) bantu pemelajar mengidentifikasi cara-cara mengawali suatu proyek belajar berikut cara memeriksa dan melaporkannya; (b) ciptakan kemitraan dengan pemelajar dengan cara menegosiasikan kontrak belajar yang meliputi tujuan, strategi, dan kriteria evaluasi; (c) jadilah manager pengalaman belajar dan hindarkan menjadi pemberi informasi (information provider); (d) bantu pemelajar memiliki teknik assessment yang diperlukannya untuk menemukan tujuan khusus apa yang harus ia buat; (e) pastikan bahwa pemelajar menyadari tujuan belajar, strategi belajar, sumber-sumber belajar yang diperlukan, dan kriteria evaluasi yang telah ditentukannya sendiri sebelumnya; (f) ajarkan keterampilan "inquiry", pengambilan keputusan, pengembangan diri, cara 
mengevaluasi kerjanya sendiri; (g) bantu mencocokkan sumber belajar dengan kebutuhan pemelajar; (h) bantu pemelajar membangun sikap dan perasaan mandiri yang relatif positif bagi belajarnya; (i) gunakan teknik-teknik yang dapat memperkaya pengalaman, seperti "problem solving" atau pengalaman lapangan; (j) kembangkan panduan belajar yang bermutu tinggi; (k) dorong kemampuan berpikir kritis dengan cara mengintegrasikan aktivitas tertentu seperti seminar; (1) ciptakan iklim keterbukaan dan kepercayaan untuk meningkatkan kinerja; (m) bantu pemelajar dari segala bentuk manipulasi dengan cara menjunjung tinggi kode etik; dan (n) berperilakulah secara etis, termasuk tidak merekomendasikan pendekatan belajar mandiri jika tidak cocok dengan kebutuhan pemelajar (http://www.ntlf.corn/html/ Iib/bib/89dig.html).

Sedangkan bagi lembaga dan karyawan lain yang terlibat dalam pendidikan dengan sistem belajar mandiri, Hiemstra (1982 dan 1985) dan Brocket dan Hiemstra (1985) merekomendasikan halhal sebagai berikut. (a) Lakukan pertemuan reguler dengan ahli yang dapat memberikan saran-saran kriteria kurikulum dan evaluasi. (b) Lakukan penelitian tentang kecenderungan (trend) dan minat pemelajar. (c) Kembangkan alat-alat yang diperlukan untuk mengukur kinerja pemelajar saat ini dan untuk mengevaluasi kinerja yang diharapkan. (d) Ingatkan dan berikan reward ketika mereka telah mencapai tujuan pembelajaran yang telah ditentukan sebelumnya oleh mereka. (e) Kembangkan jaringan belajar, lingkaran belajar, dan pertukaran belajar (learning exchange). (f) Lakukan pelatihan staf tentang sistem belajar mandiri dan perluas peluang implementasirnya.

\section{Kemampuan Belajar Mandiri}

Kemampuan dalam mengendalikan atau mengarahkan belajar sendiri seseorang pada dasarnya merupakan suatu kontinum. Grow (1991) mengklasifikasikan kontinum tersebut ke dalam empat tahap: (a) pemelajar yang tergantung (dependent learner); (b) pemelajar yang tertarik (interested learner); (c) pemelajar yang terlibat (involved learner); dan (d) pemelajar mandiri (independent learner) (http:// www.oaa.pdx.edu-/CAE/faculty/Focus/Spring96/ excerpt.html). Keempat tahapan model belajar mandiri tersebut dapat digambarkan seperti dalam tabel 2 sebagai berikut.

Tabel 2. Model Tahapan Kecakapan Belajar Mandiri menurut Grow

\begin{tabular}{|c|l|l|l|}
\hline Tahap & \multicolumn{1}{|c|}{ Pemelajar } & \multicolumn{1}{|c|}{ Peran Tutor } & \multicolumn{1}{c|}{ Contoh } \\
\hline 1 & Dependent & Otoriter, Pelatih & $\begin{array}{l}\text { Ceramah, melatih dengan umpan balik } \\
\text { langsung, drill. }\end{array}$ \\
\hline 2 & Interested & $\begin{array}{l}\text { Motivator } \\
\text { pembimbing }\end{array}$ & Ceramah + diskusi terpimpin \\
\hline 3 & Involved & Fasilitator & $\begin{array}{l}\text { Proyek kelompok, diskusi yang } \\
\text { difasilitasi oleh tutor, seminar. }\end{array}$ \\
\hline 4 & Independent & $\begin{array}{l}\text { Konsultan, } \\
\text { delegator }\end{array}$ & Kerja individu, kelompok belajar. \\
\hline
\end{tabular}

Dengan demikian, dalam pendidikan dengan sistem belajar mandiri, kecakapan dan kesiapan dalam belajar secara mandiri merupakan syarat utama. Berdasarkan tahapan belajar mandiri model Grow, pemelajar yang masih memungkinkan untuk dapat mengikuti sistem belajar mandiri adalah pemelajar pada tahap tiga (involved learners) dan tahap empat (self directed learners).

Sedangkan Robert Kizlik (2001) mengembangkan skala kecakapan dan kesiapan belajar jarak jauh (Distance Education Aptitude and Readiness Scale (DEARS)) sebagai salah satu panduan bagi para calon mahasiswa pendidikan jarak jauh. Skala tersebut terdiri atas 15 butir pernyataan dengan skala dari 1 sampai dengan 5. Mereka yang mempunyai skor 44 ke bawah, sebaiknya jangan memaksakan diri untuk mengikuti pendidikan dengan sistem belajar mandiri (dalam konteks ini, pendidikan jarak jauh) (http:// www.aclprima,com/ dears.html).

\section{Kerangka Berpikir}

Prestasi belajar sebagai kualitas dari sebuah proses belajar diperlukan untuk menghadapi perubahan-perubahan yang terjadi dalam era informasi. Salah satu penunjang dalam pencapaian prestasi belajar adalah dengan memiliki kemampuan belajar mandiri. Kemampuan belajar mandiri dapat mendorong pemelajar untuk mengembangkan kualitas pribadi. Aktivitas di kampus UNJ telah memberikan kontribusi terhadap pembentukkan kemampuan belajar mandiri yang tidak dikondisikan melalui pengalaman belajar, kegiatan organisasi, dan metode pembelajaran yang diterapkan oleh dosen. 
Pengembangan kemampuan belajar mandiri apabila dikondisikan secara terencana dan bertujuan akan menghasilkan nilai tambah pada prestasi belajar mahasiswa. Untuk mengembangkan kemampuan belajar mandiri pada tataran universitas diperlukan faktor-faktor penunjang dalam pelaksanaannya. Faktor-faktor tersebut terdiri atas faktor internal dan eksternal. Faktor internal terdiri dari mahasiswa, sedangkan untuk faktor eksternal terdiri atas dosen dan lembaga yang terkait.

Pada faktor internal (mahasiswa), aspek yang mendukung untuk pengembangan kemampuan belajar mandiri diantaranya adalah motivasi, tataran kognitif, dan kebutuhan mahasiswa akan pengetahuan. Faktor eksternal yang menunjang kemampuan dalam pengembangan belajar mandiri dapat dilihat dari aspek dosen yaitu kesiapan dosen dalam memfasilitasi metode pembelajaran mandiri dan lembaga terkait yang menyediakan fasilitas penunjang terjadinya belajar mandiri.

Dari analisis yang dikemukakan maka dapat disimpulkan bahwa pengembangan kemampuan belajar mandiri diperlukan untuk meningkatkan kualitas pribadi mahasiswa dalam menghadapi perubahan dunia, peningkatan kualitas pribadi dapat dilihat dari prestasi belajar mahasiswa (output) yang baik. Selain itu pengembangan kemampuan belajar mandiri ini diharapkan dapat meningkatkan kualitas lulusan mahasiswa UNJ agar dapat bersaing dengan lulusan-lulusan universitas lainnya.

METODOLOGI PENELITIAN

Tujuan utama penelitian ini adalah untuk mengetahui kemampuan belajar mandiri mahasiswa UNJ. Secara lebih khusus, penelitian ini bertujuan untuk mengetahui kemampuan belajar mandiri mahasiswa UNJ dipandang dari segi metode dan tujuan.

Metode yang digunakan adalah deskriptif dengan pendekatan survei, dengan kata lain penelitian ini tidak dimaksudkan untuk menguji hipotesis. Dilihat dari ruang lingkupnya, penelitian ini termasuk penelitian kasus karena hanya diberlakukan di FIP UNJ. Penelitian ini dilaksanakan di UNJ yaitu pada FIP. Penelitian ini dilakukan dalam waktu 9 bulan dimulai dari bulan Maret 2007.

Mengingat jumlah mahasiswa UNJ yang sangat banyak serta keterbatasan peneliti maka pada penelitian ini hanya meneliti populasi terjangkau yaitu mahasiswa FIP UNJ. Berdasarkan populasi ditentukan dua sumber data. Pertama, sumber data utama yaitu mahasiswa FIP UNJ. Sumber data utama ini digunakan purposive sampling. Jumlah responden yang dijadikan sumber data dari masing-masing program studi adalah 5 sampai dengan 20 mahasiswa, sehingga jumlah keseluruhan dari sumber data utama antara 45 mahasiswa sampai dengan 180 mahasiswa. Pengambilan data mahasiswa ini dilakukan kepada responden yang ditemui.

Kedua, sumber data penunjang. Sumber data penunjang berguna untuk memperkuat serta melengkapi data utama. Sumber data penunjang penelitian ini diperoleh dari dosen serta Ketua Program Studi di FIP UNJ. Jumlah keseluruhan dosen yang ditetapkan menjadi sumber data penunjang antara 18 sampai dengan 27 orang dosen, yang mewakili masing-masing program studi. Sama halnya dengan cara pengambilan data dari mahasiswa, pada data penunjang dosen ini juga dilakukan pada responden yang ditemui pada saat penyebaran instrumen. Selain dosen, sumber data penunjang lainnya adalah Ketua Program Studi di lingkungan FIP UNJ. Jumlah Ketua Program Studi di lingkungan FIP UNJ adalah sebanyak 9 orang. Namun mempertimbangkan aktivitas ketua program studi yang tidak terprediksi maka jumlah responden ditentukan antara 5 sampai dengan 9 orang Ketua Program Studi.

Dalam penelitian ini, mahasiswa mengisi dua buah instrumen, pertama adalah kuesioner skala kecakapan dan kesiapan belajar jarak jauh atau DEARS sebagai salah satu panduan bagi para calon mahasiswa pendidikan jarak jauh. Penggunaan kuesioner DEARS bertujuan untuk mengetahui kemampuan belajar mandiri dari aspek metode (sistem belajar mandiri). Instrumen kedua adalah kuesioner tertutup yang berisikan pertanyaan-pertanyaan yang menggambarkan belajar mandiri dari aspek tujuan (tanggung jawab pemelajar pada belajar mandiri). Kuesioner untuk dosen dan Ketua Program Studi berupa kuesioner terbuka yang bertujuan untuk menunjang data kemampuan belajar mandiri mahasiswa dari aspek tujuan. Kuesioner yang digunakan mahasiswa untuk mendeskripsikan kemampuan belajar mandiri dari aspek tujuan dibangun melalui teori Keesten (1987) serta teori Lewis dan Spencer (1986).

Teknik analisis untuk kuesioner skala kecakapan dan kesiapan belajar jarak jauh DEARS penghitungan menggunakan dengan skala dari 1 sampai dengan 5. Pada instrumen ini terdapat 15 butir pernyataan yang harus dijawab oleh mahasiswa. Nilai tertinggi yang diperoleh adalah 75 ; nilai tertinggi 
menggambarkan potensi tinggi dari mahasiswa terhadap belajar mandiri. Berikut adalah pengelompokkan mahasiswa berdasarkan range nilai yang diperoleh dari penghitungan kuesioner DEARS (http://www.aclprima,com/dears.html).

$55-75=\quad \begin{aligned} & \text { Kelompok (gaya belajar) yang cocok } \\ & \text { dengan belajar mandiri. }\end{aligned}$
$45-54=\quad \begin{aligned} & \text { Kelompok (gaya belajar) yang cocok } \\ & \text { dengan belajar mandiri, namun } \\ & \text { membutuhkan konsistensi }\end{aligned}$

$30-44=\quad$ Kelompok (gaya belajar) yang tidak memiliki kesulitan dengan belajar mandiri, namun akan mengalami kesulitan dengan interaksi kelas belajar mandiri.

$15-29=\quad$ Kelompok (gaya belajar) yang tidak cocok dengan belajar mandiri.

Sedangkan data yang diperoleh dari kuesioner tertutup bagi mahasiswa yang berisikan pertanyaanpertanyaan yang menggambarkan belajar mandiri dari aspek tujuan (tanggung jawab pemelajar pada belajar mandiri) serta data yang terkumpul dari kuesioner untuk dosen dan Ketua Program Studi berupa kuesioner terbuka kemudian dihitung dengan menggunakan teknik statistik sederhana kemudian dianalisis.

\section{HASIL PENELITIAN}

Secara keseluruhan penelitian ini mengarah positif terhadap kemampuan belajar mandiri mahasiswa UNJ. Kemampuan yang dimaksud tersebut secara rinci dapat disimpulkan sebagai berikut.

1. Kemampuan belajar mandiri mahasiswa dari aspek metode di UNJ

Seperti yang telah disebutkan sebelumnya bahwa data yang diperoleh untuk mengetahui kemampuan belajar mandiri mahasiswa dari aspek metode di UNJ adalah dengan menggunakan kuesioner skala kecakapan dan kesiapan belajar jarak jauh DEARS. Pada instrumen ini terdapat 15 butir pernyataan yang harus dijawab oleh mahasiswa. Nilai maksimum yang diperoleh pada instrumen DEARS adalah 75 .

Dari data diperoleh, tidak ada mahasiswa $(0,00 \%)$ yang termasuk kelompok (gaya belajar) yang tidak cocok dengan belajar mandiri, dan sedikit sekali mahasiswa $(6,62 \%)$ yang tergolong kelompok (gaya belajar) yang tidak memiliki kesulitan dengan belajar mandiri, namun akan mengalami kesulitan dengan interaksi kelas belajar mandiri. Kurang dari sebagian mahasiswa (43,05\%) termasuk kelompok (gaya belajar) yang cocok dengan belajar mandiri, namun membutuhkan konsistensi, serta lebih dari sebagian mahasiswa (50,33\%) telah tergolong kelompok (gaya belajar) yang cocok dengan belajar mandiri.

Berdasarkan pemaparan data di atas secara umum, mahasiswa telah memiliki kemampuan dasar untuk mengikuti belajar mandiri. Hal ini terlihat dari jumlah mahasiswa yang secara menyeluruh (100\%) telah mampu mengelola kemampuan belajar mandiri. Namun dari data yang disajikan di atas diketahui pula bahwa pada pelaksanaan belajar mandiri mahasiswa masih membutuhkan bantuan dari pihak lain untuk pelaksanaan belajar mandiri, hal ini ditunjukkan dengan jumlah $(49,67 \%)$ mahasiswa yang termasuk kelompok (gaya belajar) yang tidak memiliki kesulitan dengan belajar mandiri, namun akan mengalami kesulitan dengan interaksi kelas belajar mandiri dan kelompok (gaya belajar) yang cocok dengan belajar mandiri, namun membutuhkan konsistensi.

2. Kemampuan belajar mandiri mahasiswa dari aspek tujuan di UNJ

Untuk mendapatkan gambaran mengenai kemampuan belajar mandiri mahasiswa dari aspek tujuan di UNJ telah disebarkan kuesioner kepada mahasiswa, dosen, serta ketua program studi.

\section{a. Mahasiswa}

Hasil penelitian terhadap mahasiswa dapat dikatakan positif. Mahasiswa telah menjalankan konsep-konsep belajar mandiri dalam perkuliahan. Hal ini terlihat dari persentase di atas 50\% untuk setiap pernyataan yang diajukan, seperti penyataan: kesadaran akan kebutuhan belajar adalah tanggung jawab pemelajar itu sendiri; pemelajar memegang kendali dalam pengambilan keputusan untuk mencapai kebutuhan belajar; secara individu atau kelompok dapat meminta bantuan kepada orang-orang yang relevan. Selain itu mahasiswa telah pula memiliki tingkat kemandirian dalam belajar, hal ini terbukti dari tingkat kesadaran mahasiswa akan kemandirian dalam mengambil atau menentukan keputusan sendiri tentang tujuan atau hasil belajar yang ingin dicapai; kemandirian dalam mengambil atau menentukan keputusan sendiri mata ajar, tema, topik, atau isu yang akan dipelajari; kemandirian dalam mengambil atau menentukan keputusan sendiri tentang sumber-sumber belajar dan metode yang akan digunakan; kemandirian dalam mengambil atau menentukan keputusan sendiri tentang kapan, bagaimana, serta dalam hal apa keberhasilan belajarnya akan diuji.

Persentase tertinggi diperoleh dari pernyataan bahwa kebutuhan belajar adalah 
tanggung jawab pemelajar sendiri, yaitu sebanyak $96,10 \%$. Dalam pernyataan bahwa secara individu mereka meminta bantuan kepada orang-orang yang relevan untuk membantu dalam materi pelajaran juga memperoleh persentase sama besarnya, yaitu sebanyak $96,10 \%$.

\section{b. Ketua Program Studi}

Hasil penelitian pada Ketua Program Studi yang dilakukan adalah mengarah negatif. Hal ini dapat dilihat dari rendahnya persentase jawabanjawaban yang diajukan. Persentase terendah terdapat pada tiga pernyataan. Pertama adalah mengenai pelaksanaan penelitian kecenderungan dan minat pemelajar terhadap belajar mandiri, kedua mengenai melakukan pelatihan kepada staf tentang sistem belajar mandiri, dan ketiga adalah mengenai melakukan pelatihan staf tentang perluasan peluang implementasi belajar mandiri. Ketiga pernyataan tersebut memperoleh persentase yang sama yaitu hanya sebesar $16,67 \%$.

\section{c. Dosen}

Hasil data yang dilakukan pada dosen adalah mengarah positif. Hal ini terlihat dari persentase perolehan data di atas $50 \%$ pada setiap pernyataan yang diajukan. Perolehan persentase tertinggi adalah $100 \%$ dalam 5 pernyataan dari 27 yang diajukan, yaitu: tindakan dosen merangsang rasa ingin tahu pemelajar; menciptakan harapan positif; menyampaikan tujuan pembelajaran yang jelas dan berguna dalam belajar mandiri; membantu pemelajar membangun sikap dan perasaan mandiri; menciptakan iklim keterbukaan dan kepercayaan dalam pelaksanaan belajar mandiri. Persentase terendah adalah $62,50 \%$ yaitu pada pernyataan mengembangkan panduan belajar yang bermutu tinggi dalam pelaksanaan belajar mandiri. Namun walaupun data yang diperoleh mengarah positif, tetapi dosen-dosen belum memahami konsep belajar mandiri secara keseluruhan.

Dari data keseluruhan di atas dapat disimpulkan bahwa kemampuan belajar mandiri yaitu mahasiswa sudah dapat siap untuk menerapkan belajar mandiri, hal ini terlihat dari tingkat kesadaran mahasiswa akan tanggung jawab yang harus dimiliki selama proses belajar dilaksanakan. Selain itu, dari data yang telah diperoleh, diketahui bahwa dosen juga telah mendukung upaya-upaya yang dalam melaksanakan belajar mandiri walaupun pemahaman tentang konsep belajar mandiri masih sangat rendah. Upaya yang diberikan selama pelaksanaan belajar seringkali tidak disadari bahwa mereka telah menerapkan belajar mandiri. Andai saja dosen telah mengerti konsep belajar mandiri dengan baik maka penerapan belajar mandiri dapat terlaksana dengan maksimal. Namun, Ketua Program Studi belum melakukan upaya-upaya terselenggaranya pelaksanaan kemampuan belajar mandiri mahasiswa UNJ.

\section{Keterbatasan Penelitian}

Pada penelitian ini terdapat keterbatasan yang dapat peneliti identifikasi selama melakukan penelitian. Adapun keterbatasan dalam penelitian ini yaitu: (1) pengumpulan data yang memakan waktu cukup lama, (2) kerja sama yang sulit dalam pengumpulan data dengan dosen dan ketua program studi, (3) banyaknya jumlah responden, dan (4) pemahaman atas butir-butir pertanyaan kemampuan belajar mandiri bagi responden sekunder sulit diprediksi.

\section{KESIMPULAN}

Berdasarkan pertanyaan rumusan masalah maka hasil penelitian ini dapat dikelompokkan menjadi dua kategori yaitu kemampuan belajar mandiri dilihat dari aspek metode dan dilihat dari aspek tujuan. Pada aspek metode dapat disimpulkan bahwa secara keseluruhan mahasiswa UNJ telah siap atau mampu dalam melaksanakan metode belajar mandiri.

Dalam aspek tujuan dapat disimpulkan bahwa mahasiswa dapat bertanggung jawab terhadap diri sendiri terhadap pelaksanaan belajar mandiri, dan dosen juga telah mendukung upaya-upaya dalam melaksanakan belajar mandiri walaupun pemahaman tentang konsep belajar mandiri masih sangat rendah. Namun, Ketua Program Studi belum melakukan upaya-upaya terselenggaranya pelaksanaan kemampuan belajar mandiri mahasiswa UNJ.

\section{Implikasi}

Sejalan dengan kesimpulan dalam penelitian ini maka secara umum implikasi yang terjaring pada penelitian ini adalah masih sangat kurangnya faktor penunjang dalam pelaksanaan belajar mandiri, sedangkan secara khusus peneliti mendapatkan implikasi dari penelitian ini yang dirumuskan dan ditujukan kepada, dijelaskan sebagai berikut.

1. Pimpinan UNJ pada umumnya dan pimpinan FIP pada khususnya selaku pengambil kebijakan, antara lain sebagai berikut.

a. Pelaksanaan belajar mandiri di universitas hanya dapat dilakukan jika terdapat sarana yang mendukung, dimulai dengan penambahan jumlah sumber belajar pendukung seperti 
buku terbaru, jaringan komputer yang memadai dalam pelaksanaan belajar mandiri dengan sistem on-line learning, dan pengembangan kualitas laboratorium-laboratorium.

b. Untuk mendukung pelaksanaan belajar mandiri, pimpinan universitas dapat melakukan pelatihan secara berkala kepada dosen dan mahasiswa guna memahami lebih dalam mengenai konsep belajar mandiri dan penerapannya di universitas. Dalam mempersiapkan melaksanakan belajar mandiri di universitas pimpinan harus menyeluruh dalam memutuskan kebijakan, hal ini dikarenakan terdapat perbedaan karakteristik antar masingmasing program studi di UNJ.

2. Bagi dosen dalam peningkatan kualitas dosen yang profesional yaitu pelaksanaan belajar mandiri membutuhkan kesiapan dosen untuk merancang dan menerapkan konsep belajar mandiri yang benar pada perkuliahan. Masih terdapat kendala bagi dosen dalam melaksanakan belajar mandiri karena pengetahuan dan kemampuannya yang minim dalam belajar mandiri. Oleh karena itu, diharapkan dosen selalu membuka cakrawala dalam perkembangan dunia pendidikan.

3. Bagi mahasiswa selaku peserta didik yaitu pelaksanaan belajar mandiri menuntut mahasiswa mampu untuk berperan aktif dalam tiap proses belajar mandiri, oleh karena itu diharapkan mahasiswa harus mampu melaksanakan constructivism dan active learning.

\section{Saran}

1. Bagi mahasiswa yang termasuk golongan rendah dalam menjalankan belajar mandiri, dalam pelaksanaannya membuat jadwal pertemuan tutorial dengan dosen yang bersangkutan.

2. Bagi Ketua Program Studi agar menjembatani pelaksanaan belajar mandiri antara dosen dan mahasiswa.

3. Bagi dosen, agar memperkuat atau memperjelas konsep belajar mandiri sehingga pada pelaksanaannya akan berjalan lancar.

\section{DAFTAR PUSTAKA}

Candy, P.C. "Independent: Some ideas from literate". (http://www.brookes.ac.uk/services/ocds/ 2_laerntch/indepedent.html)
Cuya Hoga Community College. (http:// www.dlc.trec.cc.ch.us/doc/il.html).

Grow, G. (1991). Teaching learning to be self-directed, Adult Education quarterly. (http://www. oaa.pdx.edu/CAE/faculty/Focus/Spring $96 /$ excerpt.html)

Heinich, R., Molenda, M., Russel, J.D., (1993). Instructional media (4th Edition). New York: MacMillan Publishing. Co.

Irene S. C. S. Foresting self-directed learning readiness by way of PBL intervention in bussiness education. Open University of Hongkong, available at (http://www.tp.edu.sg/pblconference/full/ ireneSiaw.pdf).

Karhami, S. K. A. (http://www.depdiknas.go.id/ jurnal/35/mengubah_wawasan peran.htm, diakses tanggal 7 Agustus 2007)

Kizhk, B. (2001). “Getting ready for distance education: Distance education aptitude and readiness scale (DEARS)". (http://www.aclprima,com/ dears.html).

Lowry, M. C. (2001). "Supporting and facilitating self directed learning". (http:// www.ntlf.corn/ html/Iib/bib/89dig.html).

Open University of Hongkong. (http://www.tp. edu.sg)

Penns' State University. Independent learning student guide. (http//www.utreach.edu/DE/il.html)

Reay, D. G. (1994). Understanding how people learn. London, New Jersey: Kogan Page Ltd.

Regina, S. K. Chapter VII: Independent learning (dalam Understanding The Common Essential Learning)". (http://www.sasked.gov.sk.ca/ does/policy/cels/cl17.html)

Rowntree, D. (1992). Exploring open and learning. London: Kogan Page Limited.

\section{KETERANGAN PENULIS}

Dra. Suprayekti, M.Pd., dilahirkan di Jakarta, Oktober 1960. Saat ini penulis aktif sebagai Dosen KTP FIP UNJ dan Penatar PEKERTI (Program Pengembangan Ketrampilan Dasar Teknik Instruksional) di Perguruan Tinggi. Penulis menghasilkan karya terbarunya di tahun 2007 yaitu Perencanaan Pembelajaran. 